

\section{EUROPEAN UNIVERSITY INSTITUTE}

|||||||||||||||||||||||||||||||||||||||||||||||||||||||||||||| 
EUROPEAN UNIVERSITY INSTITUTE, FLORENCE

ROBERT SCHUMAN CENTRE

Democracy and Enlarging the

European Union Eastwards

RICHARD ROSE and

CHRISTIAN HAERPFER

WP

321.0209

4 EUR

EUI Working Paper RSC No. 95/12

BADIA FIESOLANA, SAN DOMENICO (FI) 
All rights reserved.

No part of this paper may be reproduced in any form without permission of the authors.

(C) Richard Rose \& Christian Haerpfer

Printed in Italy in September 1995

European University Institute

Badia Fiesolana

I - 50016 San Domenico (FI)

Italy 


\title{
DEMOCRACY AND ENLARGING THE EUROPEAN UNION EASTWARDS
}

\author{
Richard Rose, University of Strathclyde
}

$\&$

Christian Haerpfer, Paul Lazarsfeld Society, Vienna

\section{Acknowledgments}

The research reported here has been aided by a grant to the first-named author from the United States Institute of Peace, Washington DC, to study cooperation and conflict avoidance in the European Union at the Robert Schuman Centre of the European University Institute, Florence. Rose is also indebted to Frank Vibert, director of the European Policy Forum, London, for stimulating an earlier paper on this subject, presented at seminars in London and Vienna. Both authors are grateful for the continuing support of the New Democracy Barometer by the Austrian Ministry for Science and Research and the Austrian National Bank. This paper will also appear in a special issue of the Journal of Common Market Studies (September, 1995) on post-Communist societies and the new Europe. 
Abstract
Democracy is a precondition for membership in the European Union. What are the chances for democracy in the post-Communist states of Central and Eastern Europe? The first section states arguments of doubters; the second and third present fresh empirical evidence from nationwide surveys of public opinion in the Czech Republic, Slovakia, Hungary, Poland, Slovenia, Bulgaria and Romania. Survey data shows widespread popular support for the current regime as against the old Communist regime, and no substantial support for undemocratic alternatives. The critical feature of ex-Communists is that they are now "ex". Given that the democratic precondition is met, the paper secondly considers: What are the obstacles to enlargement within post-Communis countries? In Central and Eastern Europe the chief obstacle is the time required to create all the institutions of the market. Within the European Union there is also an obstacle, defining the post-1996 acquis communitaire, a task made more complex by the prospect of adding new member states from Central and Easterm Europe. 
The Baltic Sea is just as much a European one as the Mediterranean. It is quite simply intolerable for us to adopt the attitude that we want to create some sort of closed shop.

Helmut Kohl, on enlargement of the European Union (Bridge, 1994)

The fall of the Berlin Wall and the Soviet Union have transformed the map of Europe. Politics no longer imposes artificial divisions upon geography. Prior to 1945 Prague, Budapest and Warsaw were just as much European cities as Rome, Madrid and Lisbon. The 1995 expansion of the Union plus German reunification has moved the Union's centre of gravity well to the east of Brussels. Austria shares boundaries, with four former Communist states--the Czech Republic, Slovakia, Hungary and Slovenia--and Germany shares boundaries with Poland and the Czech Republic, as well as incorporating 16 million former citizens of a Communist party-state. The Baltic states of Sweden and Finland are geographically closer to Warsaw and St. Petersburg than to Brussels. As Chancellor Kohl's remark emphasizes, Central Europe is once again central in European politics.

The enlargement of the European Union is an ongoing process. Since foundation, it has more than doubled in number of member states and greatly increased its cultural, social and economic heterogeneity. The Maastricht Treaty re-emphasizes the openness of the EU to additional members: "Any European 
State may apply to become a Member of the Union'. The EU has now recognized six countries as candidates for membership--the Czech Republic, Slovakia, Hungary, Poland, Bulgaria and Romania. In addition, Estonia, Latvia and Lithuania have been given a special status as potential applicants for membership, and Slovenia too has a special status.

The EU, unlike the United Nations and the International Monetary Fund, has a political criterion for membership, democracy. In the Mediterranean, the Union saw membership as a means of reinforcing the process of democratization there. Instead of waiting a generation or more for overwhelming evidence that democracy was fully institutionalized, Greece was admitted seven years after iv adopted a democratic constitution and Spain and Portugal little more than decade after the collapse of long-lived authoritarian regimes. On such a timetable, post-Communist regimes could start entering the European Union around the end of this decade.

What chance is there for democracy in post-Communist states of Centrai and Eastern Europe today? A glance at the past would suggest that the answer is 'very little', since before becoming Communist most were ruled by conservative, military or populist authoritarian regimes, and some sided with the Axis in the Second World War. But who would have thought half a century ago that Germany would now be an exemplar of stable democracy? Among the 15 current member states of the European Union, less than half can claim an uninterrupted history of democracy extending back before the Second World. France has had three different regimes and four constitutions since 1939. Seven states--Germany, 
Austria, Italy, Spain, Portugal, Greece and Finland--have institutionalized new democratic regimes since the end of the war.

At a minimum, the countries of Central and Eastern Europe have moved away from the totalitarian aspirations of a Soviet-style Communist party state. In its annual review of freedom on every continent, Freedom House (1994: 20) describes Bulgaria, the Czech Republic, Hungary, Poland and Slovenia as free, and Romania and Slovakia as 'partly free'. All seven countries are classified as much freer today than five years ago. Free competitive elections were introduced throughout the region in 1990 (White, 1990), and each country has now held at least two free competitive elections. As a result of swings in electoral or parliamentary support, control of government now changes hands peacefully in the majority of Central and East European countries. Such a change of government did not occur in the Federal Republic of Germany until 20 years after it was founded, in the Fifth French Republic until 23 years after foundation and in Italy the Christian Democrats were continuously in office and the second largest party continuously excluded until the debacle of established parties in 1994.

Democracy is a necessary but not sufficient condition for membership in the European Union. To participate in the Single Europe Market, a country must. have a functioning market economy. Post-Communist societies have found it a more difficult and slower task to introduce the institutions needed for a market economy than to introduce free elections. Applicants must also accept the acquis communitaire. For this to happen, the member states of the EU must agree on what the acquis will be by the time that Central and East European countries are 
ready for membership. The 1996 Inter-Governmental Conference is intended to address this point. While the initial purpose of the IGC was to address problems of deepening the commitment of existing members, the issues--the Common Agricultural Policy, fiscal affairs, EMU, voting rights, military security and "two-speed" or "variable" forms of commitment--have major implications for dealings with Central and East European countries too.

Hence, this article first poses and answers the question: What are the chances for democracy in Central and Eastern Europe? ${ }^{1}$ The first section presents the arguments of doubters; the second and third sections present fresh empirical evidence of surveys of public opinion throughout the region. Given that the democratic precondition is met, the second purpose is to consider: What are the real obstacles to enlargement? The two concluding sections focus on the problems of introducing a market economy in place of a command economy. and the difficulties that current EU members face in defining the post-1996 acquis communitaire

\section{CAUSES FOR CONCERN?}

In distant times the lands of Central and Eastern Europe were ruled as part of authoritarian Russian, Ottoman, Habsburg and Prussian empires. Between the wars, the norm was a short experiment with semi-free elections, followed by an authoritarian takeover. Among the states examined here, only Czechoslovakia could claim to have established a democratic regime prior to the outbreak of the Second World War. More disturbing is the legacy of recent history, four decades of Communist rule. 
Votes for ex-Communists In democratizing regimes, free competitive elections not only determine which parties win the most seats in Parliament, but also show how much or how little popular support there is for anti-democratic parties. In such long-established democracies as Britain and Scandinavia, fascist and communist parties consistently receive very few votes.

In the first post-Communist elections of Central and Eastern Europe, the Communist label and symbols were voluntarily abandoned by those who had previously been party leaders and activists. But no country has forbidden exCommunists to vote or engage in party politics. Parties are formed by exCommunists, drawing upon their organizational and financial resources, networks and personal skills. It is significant that they choose to be described as ex-Communists rather than to keep the name of the old party alive.

Electoral support for parties of ex-Communists has varied greatly from country to country. The fragmentation of votes among many parties is a caution against confusing a relatively 'big' party with a majority party. Electoral systems have often produced very disproportional results in the award of parliamentary seats, sometimes to the benefit of parties of ex-Communists.

In three countries ex-Communist parties are playing a significant role in the formation of governments. In Bulgaria the Socialist Party has averaged 41 per cent of the vote in the three post-Communist elections. In Poland the exCommunist Democratic Left and the Peasants' Party together won 21 per cent of the vote in the 1991 Sejm election. Building on discontent with the government 
of the day, in 1993 the two parties together won 36 per cent of the vote. The mechanics of a very disproportional PR electoral system converted this into 66 per cent of the seats. In Fungary. the Socialist Party won 11 per cent of the vote in 1990 and in 1994 it won the largest share of the popular vote, 33 per cent. With a lower share of the vote than the Labour Party took at the 1992 British general election, the Socialists managed to take 54 per cent of the seats in Parliament.

In Czechoslovakia the Communist Party won 14 per cent of the vote in the 1990 election of the Chamber of the People. In 1992 the Left Block won 14 per cent of the vote in the Czech Republic and the Party of the Democratic Left (SDL) a similar amount in the Slovak Republic. Insofar as there are threats to democracy in Slovakia they are more likely to come from nationalist than Communist sources. In the October, 1994 Slovak election, a party of exCommunists, Common Choice, came second with 10 per cent of the vote. In Slovenia, the special circumstances of the break up of Yugoslavia has made party ideology less important than attitudes toward Belgrade. In the 1992 parliamentary election, the United League of ex-Yugoslav Communists won $1 \mathrm{~s}_{\mathrm{e}}$ per cent of the vote. In Romania the personalistic or Sultanistic character of Ceausescu's rule encouraged dissent among members of the national Communist party. There too threats to democracy are more likely to come from traditional nationalist and authoritarian tendencies than from Marxist-Leninist legacies.

East Germany is sometimes cited as if it were an example of Communist revival, because of support for the Party of Democratic Socialism (PDS). In fact, it represents exactly the opposite. The PDS cannot hope to win power in the 
Federal Republic because it only contests seats in the five laender of the old German Democratic Republic. In 1990 it won only 11 per cent of the vote in that region, 2 per cent of the total for Germany as a whole. In 1994 the regional PDS vote doubled to 22 per cent as it campaigned on regional grievances, exactly the opposite of the behaviour of an internationalist Marxist-Leninist party. The PDS remains small at the national level, nor has it called forth a rightwing reactionary party in West Germany. While it is correct to say that East Germans do see the collapse of Communism differently from West Germans, in fact a major difference is that East Germans see re-unification as greatly improving their economic prospects, and simultaneously giving them a better political regime (see Rose and Page, 1996).

Where parties of ex-Communists have been successful in winning elections, they have not done so by promising a return to a Communist regime but by promising more effective government within the framework of pluralist. elections and freedoms. When a government of inexperienced politicians runs into difficulties, ex-Communists point to their experience of office. In Hungary, the Socialist leader, Gyula Horn, campaigned against a conservative government by proclaiming: 'Let the experts govern' (Barber, 1994). Within a year, his own government split when confronted by persisting economic difficulties. In Poland President Walesa has been able to exploit differences among ex-Communists. In a competitive party system, ex-Communists must learn new tricks in order to survive.

Economic transformation. Marxists believed that the collapse of a capitalist economic system would lead to political revolution. In the event, the 
collapse of Communist political regimes has produced an economic counterrevolution, as the power of the bureaucratic commanders of the command economy was broken (cf. Kornai, 1992). Post-Communist countries are now in the throes of economic transformation. In this process, costs come before benefits. To paraphrase Lenin, "You can't introduce a market economy without breaking eggs". The results are evident at both the macro-economic and the household level (cf. World Bank, 1993). They include:

Official statistics record the double-digit contraction of the official economy since 1990 (World Bank, 1993). On the basis of official statistics ? Lawrence Summers (1992: 25ff) has compared per capita income in Central an Eastern Europe as between Argentine and Korea today, or at the level of the United States in 1900. His 'conservative' estimate is that these countries will no: see their per capita income return to the 1989 level for seven to ten years (that is, 1996) and not regain their position relative to expanding West European economies until about 2005. Even if these numbers are discounted as inadequately taking into account "unofficial" economic activity, there has almost certainly been some loss of output and substantial economic dislocations (Holzmann et al., 1995).

Treble digit inflation has been the norm. When inflation rates are calculated for a two or three year period, the cumulative effect can be quadruple or even quintuple digit inflation. Quoting inflation rates in monthly terms does not alter the underlying arithmetic: a 20 per cent monthly rate compounds into an annual inflation of 1,070 percent. If the rate then falls to 'only' 10 percent a month, in two years prices will rise by 2,475 percent from the base. 
Unemployment is a rising threat. A nonmarket economy could offer a low paid job for life, but an economy in transformation necessarily requires labour mobility. Insofar as enterprises traditionally relied upon overemployment, then one step toward efficiency is to shed labour. If that does not work, then forced down-sizing or bankruptcy can make people unemployed. Reported unemployment rates in Central and Eastern Europe today are no higher (and sometimes lower) than in OECD countries. But people in employment are in a far more precarious situation, for even if they do not lose their job, the wages they are paid may badly deteriorate in value.

\section{POPULAR EVALUATION OF NEW REGIMES}

If Central and East Europeans remain committed to authoritarian traditions, if economic difficulties invariably lead to the rise of undemocratic regimes and if Communists are unyielding adherents of Marxist-Leninist doctrines, the European Union would become, on its own or in conjunction with NATO, a bastion of democracy in a still-divided continent. But are Central and East Europeans voting for a return to the authoritarian and anti-market regime of. the past forty years? Or are ex-Communists simply showing their true colours as political opportunists?

In an open society there is a straightforward way to assess the chances of democracy: Ask the people A democracy cannot exist unless it is freely supported by the bulk of the population. Furthermore, most predictions of the return of authoritarianism forecast a populist leader winning a free election or 
suspending Parliament and introducing authoritarian governance with the tacit support of a majority.

To monitor popular response to transition, the Paul Lazarsfeld Society, Vienna, has established the New Democracies Barometer (NDB), a unique annual survey of political attitudes and economic behaviour in post-Communist countries. The data reported here come from the third annual New Democracies Barometer, financed by the Austrian Ministry of Science and Research and the Austrian National Bank. It asks the same questions of nationwide stratified representative samples averaging one thousand respondents across Central and: Eastern Europe. The results here are for the Czech Republic, Slovakia, Hungary Poland, Bulgaria and Romania and Slovenia. ${ }^{2}$ The results reported here are for 7,020 face-to-face interviews. Fieldwork was conducted between late November, 1993 and early April, 1994 (for full details, see Rose and Haerpfer, 1994). To assist generalization, the following tables also report a New Democracies mean, calculated by averaging the responses from all seven countries, weighting each as equal in size. The first two tables also give results for East Germany from a spring, 1993 representative sample survey of 1,117 East Germans (see Rose Zapf et al., 1993).

Erom a state-centric perspective, the key question is the stability of a regime. If a regime is unlikely to last for more than a few years, it would be imprudent for any country to agree a long-term treaty commitment. EU negotiators also have a second concern: whether or not there is likely to be a democratic regime. A democratic regime necessarily depends upon a substantial degree of popular endorsement. ${ }^{3}$ 
By definition, everyone in an ex-Communist society has lived under at least two different regimes, and older people have lived under three or even more. For people who have lived most of their lives in a Communist state, the starting point for evaluating any post-Communist regime is the past--Today, citizens of the new democracies are able to compare a regime in which the party, not the people, was the ultimate arbiter, and a pluralistic political system as it actually is. Such a system is bound to have defects. As Winston Churchill (1947) once told the House of Common: 'No one pretends that democracy is perfect or all wise. Indeed, it has been said that democracy is the worst form of government, except all those other forms that have been tried from time to time.'

The New Democracies Barometer asked people to evaluate regimes on a vertical "heaven/hell" scale running from +100 to -100 . Allowing for minus as well as plus ratings is important, for people can thus indicate whether both regimes are acceptable or both undesirable, with one being less unsatisfactory than the other. The question asked was: 'Here is a scale for ranking how the government works. The top, plus 100, is the best; at the bottom, minus 100, is the worst. Where on this scale would you put: a) the former communist regime b) our present system of governing with free elections and many parties? c) our system of governing in five years time?' A parallel question was asked about economic systems.

Comparing past and present. When asked to rate the former Communist regime, Central and East Europeans divide: the majority are negative, but 41 per cent give a positive rating to the old Communist system (Table 1). The lowest 
proportion is found in the Czech Republic, where Soviet repression was particularly evident. East Germans and Slovenes come second in the low level of support for the old regime. The highest rating is found in Hungary, reflecting the fact that the old regime was not so much based on repression as on hypocrisy. In Janos Kadar's phrase, 'He who is not against us is with us'. The relatively high level of endorsement in Slovakia is likely to reflect some Slovaks preferring to be part of Czechoslovakia.

When people are asked to rate the former economic system, the overali pattern is positive: 60 per cent give it a favourable rating (Table 3). Hungarians and Slovaks are very heavily positive about the old economic system. East Germans, who were relatively well off compared to other command economies in the old days, are most likely to see the old economic system as unfavourable since they can now compare it with life in the prosperous social market economy of the Federal Republic. In the Czech Republic and Slovenia, now the most prosperous post-Communist economies, less than half also endorse the olä economic system. In sum, the median person liked the security of the ol economy but not the repressive politics that accompanied it.

(Tables 1 and 2 about here)

When people are asked to rate their new political system, a clear majority are positive; an average of 61 per cent endorse their new regime. Especially positive groups are found in the Czech Republic and Poland, where repression had been harsh under an alien Communist regime. However, when people are asked about the new economic system, which has delivered inflation and rising unemployment as well as new goods to the shops, the majority are negative. Only 39 percent endorse the economy in transformation, a drop of 21 percentage 
points compared to evaluations of the planned economy. East Germans are average in their positive response to the new political system. In rating the economic transformation, they are deviant in keeping with their deviant experience of having costs met by the revenues of the Federal Republic of Germany: 75 per cent are positive about the social market economic system of the Federal Republic, almost double the proportion in economic systems in transformation.

If people prefer the new regime to the old regime and are optimistic about the future, the chances for democracy look good. But if people prefer the old to the new and are pessimistic about the future then the prospects are high for regimes to take a right or left turn away from democratization. Central and East Europeans have a mixed view of their world--but the mix is different than before. Today, the median person is positive about the political system and negative about the economic system. Combining the evaluations that people give about the past and present political systems yields a fourfold typology of responses to transformation (cf. Rose and Mishler, 1994). ${ }^{4}$

*Democrats (disapprove Communist regime, approve new: $37 \%$ ). This is the largest and most positive group. Their average rating of the old regime on the heaven/hell scale was minus 57 ; their average rating of the new regime is plus 44 .

*Sceptics (disapprove both regimes: 21\%). Sceptics view their present political system negatively. But they also view the old Communist regime as even worse, placing it 17 points lower (minus 46 ) on the heaven/ hell 
scale. Following Churchill's dictum, the present is preferred as a lesser evil than the past.

${ }^{*}$ Compliant (approve both Communist, new regimes: 22\%). Given a history of authoritarian pressures to bow to the powerful, it is not surprising that some Central and East Europeans will endorse both old and new regimes. The mean rating is identical for the Communist regime and the current regime (plus 45 points on the scale).

${ }^{*}$ Reactionaries (approve Communist regime, dislike new: 18\%). This group is the mirror image of the democrats. The mean rating given the Communist regime on the heaven/hell scale is plus 55 and the rating for the new regime is minus 41 . It differs in being almost a third smaller in size than the democrats.

The big benefits that the new regimes of Central and Eastern Europe have delivered are political. The great majority now feel much freer in their everyday life (Table 3). When the New Democracies Barometer asked people to compare conditions on six different measures of freedom, countries differ only in the size of the majority feeling freer today. Instead of being lectured about the dangers of religion as the "opiate of the people", people feel freer to decide for themselves about going to church. Instead of being forced to take part in the "non-politics" of the Communist Party, people feel free to turn their backs on participating in party politics. The biggest gains in freedom are not in the societies closest to Western standards but in societies that Communists dragged toward Oriental despotism, such as Romania. There nine-tenths now feel freer than in Ceausescu's regime. While the phrasing of questions differed in East German, a similarly high 
proportion of East Germans also report a much higher sense of freedom. The same is true for Russians in Estonia and Latvia (Rose, 1995: Figures 2, 3).

(Table 3 about here)

Future hopeful not fearful. Hope and fear are the two emotions driving Central and East Europeans today. The pessimists fear that the future may resemble the past; the optimists hope that the costs of abandening one system for another will produce benefits in future.Five years is a period in which a great deal can happen; for example, a survey such as the New Democracies Barometer could not have been conducted in 1989. Hence, the Barometer asked people to evaluate what they believe their country will be like five years from now.

Expectations of the future help us understand the direction in which sceptics and reactionaries are moving. If groups currently negative about democratizing regimes were also negative about the future, then post-Communist societies would be headed for political polarization of a sort that led to the destruction of the Fourth French Republic and crippled the Republic of Italy. Alternatively, those who are currently negative may simply be laggards in accepting change. In fact, those not currently in favour of the new regime are laggards rather than confirmed anti-democrats. The average reactionary expecis to come around to support the new regime, and so too does the average sceptic (for details, see Rose and Mishler, 1994).

Central and East Europeans are very positive about the political future: 78 per cent give a positive rating to the regime as they expect it to be (Table 1). Political optimism is high not only in the Czech Republic, but also in Romania and Bulgaria, where an undemocratic Balkan past looms large. Notwithstanding nostalgia, the great majority of Hungarians are prepared to be optimistic about 
the future. Expectations of the future economy are positive too; 70 per cent expect it to be satisfactory in five years. Here again the Czechs are most positive about the future, followed by East Germans. The majority positive about the future of the economy is not as large as that for the new political regime, but it is high enough to show there is support for both elements in the double transformation of Communist societies into democracies and market economies. Moreover, the gap between political and economic evaluations shows that it is fallacious to infer political evaluations from current economic conditions.

\section{SUPPORT FOR ALTERNATIVES TO DEMOCRACY}

The consolidation of democracy does not require 100 per cent popular endorsement of the regime, for total agreement is not possible in politics. Moreover, free elections offer openings to parties that may oppose the regime. The critical point, as studies of democratization in Mediterranean Europe emphasize (see Gunther, 1995), is that, like it or not, all politically significant groups accept a democratic political system as the regime within which they seek office and resolve their disputes. Fut institutionalization, that is, virtually unanimous support for the new regime and the disappearance of anti-regime parties, can come later. As studies of democratization in the postwar Federal Republic of Germany have demonstrated, the institutionalization of regime support in the mass population can take decades (Weil, 1989).

In post-Communist countries, potential threats to democracy could come from popular support for some kind of authoritarian regime or individuals continuing to hold Communist values even in the absence of a Communist party. The New Democracies Barometer collected data on both points. 
Alternative regimes. Since everyone in a post-Communist society has lived under at least two different regimes, it is meaningful to ask people whether they think they would be better off with another system of government (Table 4). A question about the monarchy was included, even in countries which had no royal family between the wars, as a check on the possibility of people being so alienated as to endorse anything. In countries with a republican tradition only a handful endorsed this alternative. In Bulgaria and Romania, where there were monarchs between the wars, less than one-fifth endorsed return to such a system.

Communist rule is rejected by 85 per cent of New Democracies Barometer respondents. Even in Bulgaria, where an ex-Communist party has successfully adapted to competitive party politics, only one-quarter endorse a return to a regime run as Communists used to govern. Opponents are much more intense than proponents of the old regime. In the seven countries examined here, only four per cent strongly endorsed a return to Communist rule, whereas 60 percent are strongly against a return. The low level of demand for a return to Communist rule shows that the minority approving the old regime (Table 1) are no longer actively reactionary, wanting to turn the clock back. Only 11 per cent give the Communist regime a positive rating and would like to see it back. More than two-thirds of those favourable toward the old regime are simply nostalgic about the security and order of the past without wanting the regimentation and controls that went with it.

(Table 4 about here)

In many parts of the world military rule is an alternative to democracy. The New Democracies Barometer found that among 16 different institutions in 
society the army ranked third in trust, well ahead of Parliament and political parties. Yet only 9 per cent would welcome the army governing their country. The rejection of the military is consistent with the doctrine of Communist regimes, which trained soldiers to see their role as fighting a global war rather than to enforce internal order or modernize society, tasks of the Communist Party.

The demand for effective leadership is not necessarily undemocratic: it can be heard in every American presidential election and in Western Europe too. However, given the history of Central and Eastern Europe, an effective leader may not be a democrat. Among NDB respondents, 30 percent endorsed a strong leader. Disagreement about who the strong leader should be would weaken the mass base of support for a particular dictator. Furthermore, many who favour a strong leader do so because they want more effective government; their ideal is a representative Parliament and a strong executive. Overall, only 12 per cent favour a strong leader and the abolition of Parliament (see Rose and Mishler, 1994a).

The prime problem facing every Central and East European country today is the transformation of the economic system from a command to a market economy. This is often defined by a technical problem by international advisors and by the economics profession. Elected politicians may accept allowing economists to make decisions in the belief that economics is an applied science, and they lack knowledge of what to do. Or they may push expert economists into the limelight so that others carry responsibility for unpopular policies. 
When people are asked if they would like the most important decisions about the economy to be made by experts and not elected politicians, there is very strong support in every country for a technocratic solution to current economic difficulties. The fact that 71 percent endorse decisionmaking by experts does not mean that $\mathrm{PhDs}$ from MIT are going to supplant commissars as the new ruling elite. The definition of an expert is not based on professional credentials but pragmatic: an expert is a person who can successfully address the country's economic problems.

The values of ex-Communists? Communist parties concurrently pursued two goals: they sought to indoctrinate the mass of the population in MarxistLeninist doctrines. Party propaganda was pervasive in society. In addition, Communist regimes were mobilization regimes. The intent was to make each nation's Communist Party a broad church of true believers, and not just an ideological sect. In consequence, there are now tens of millions of former members of the Communist Party in Central and East Europe today. When the Soviet Army withdrew after 1989, virtually no Communist left his or her country. This leads to the paradoxical question: How Communist were the Communists?

The greater the size of Communist Party membership, the more its members were likely to be a cross-section of the population as a whole. Communist organizations made a special effort to recruit members on the grounds of social representativeness rather than sophisticated ideological knowledge. In every Western country for which there is survey evidence, the median person has limited knowledge of politics, and is certainly not an 
ideologue. Moreover, in Communist societies there were many motives for individuals to join the Communist Party: the need to have a party card to get a position or a promotion, a liking for social activities or holding an official status, an inclination to participate in many kinds of voluntary associations, idealistic belief in simple shibboleths or a commitment to Marxist-Leninist ideology (White and McAllister, forthcoming).

Insofar as the Communist Party attracted members on ideological grounds, then the hypothesis is: the political views of ex-Communists should be very different from other members of society today, as those who silently or sullenly refrained from joining the party are now free to express their own attitudes. But insofar as people joined the party for opportunistic reasons or viewed politics in pragmatic terms, then the opposite hypothesis should hold: the political views of ex-Communist should not differ from those of other members of society. ${ }^{5}$

Given that party membership was usually not secret in Communist societies, the New Democracies Barometer found no hesitancy in people answering questions about it. Across the countries surveyed, 16 per cent said that they had belonged to the party or one of its associated organizations and an additional 18 per cent said that a member of their family had belonged to the party. Overall, more than a third could be described as being ex-Communists or having a Communist family background.

It appears that mass recruitment to the Communist Party was selfdefeating ideologically. When comparisons are made across the eleven questions reported In Tables 1-3 plus a question about suspension of Parliament, people 
who joined the party today hold similar views to non-Communists. Both groups are virtually identical in their readiness to endorse the current political regime and in their hopes for the future. While ex-Communists are more in favour of the old regime it is by only a limited margin. Ex-Communists are likely to approve the old economic system and disapprove the present way of running the economy, but the same is true of non-Communists. Both groups are similarly hopeful about the future.

(Table 5 about here)

Ex-Communists are as ready as non-Communists to support the democratic "rules of the game". The fall of an old regime plaees former rulers in opposition, giving them an incentive to respect rules that give those-out of office all the rights that oppositions have in established democracies (see di Palma, 1990). The proportion who would approve the suspension of Parliament is actually four percentage points lower than among non-Communists, and the proportion endorsing a strong leader is six percentage points lower. More than four-fifths of ex-Communists say that they now feel freer to say what they think. It is also striking that more than four-fifths of ex-Communists do not endorse a return to Communist rule.

Whatever the chances of democracy, the likelihood of a return to Communism in the countries reviewed here is almost nil, for the institutions that introduced and sustained Communism in Central and Eastern Europe--the Soviet Union and the Communist Party of the Soviet Union--no longer exist. The oldestgenerations are most likely to be nostalgic about the old regime. In Central and Eastern Europe 49 per cent of the generation born before 1933 endorse the old political system, but among the generation born after 1966 only 33 percent do so 
(Rose and Carnaghan, 1995: Table 2). As the most pro-Communist cohort dies, the balance of the population will tip, creating a society dominated by the postCommunist generations.

It can be argued that the views voiced today by self-described exCommunists are different from what they would have said five years ago. This implies that people joined the Communist party so as to advance their own interests, and 'Once an opportunist, always an opportunist. (Cf. Schumpeter's (1952: 282f) dictum that parties are like garment manufacturers, producing policies according to what appeals to their eustomers.) From this perspective, changing the political regime becomes sufficient to turn Communists into democrats, because it creates new incentives. It also imposes penalties for holding to past beliefs and practices. The problem of ex-Communists is not proving their commitment to the welfare state but in proving their commitment to liberal democratic values. Kitschelt's (1995) interviews with party elites in Central Europe show that they are now trying to do so.

\section{OBSTACLES TO ENLARGEMENT WITHIN POST-COMMUNIST COUNTRIES}

While post-Communist publics may be similar in their political preferences, there are differences between states, not least in their approach to the European Union. Such differences are most obvious between the four Visegrad countries--the Czech Republic, Hungary, Poland and Slovakia--and other postCommunist states in the region. Differences can also be found between and within the four Visegrad countries (see Kolankiewicz, 1994). There are also very 
substantial economic differences among post-Communist countries, whether the measure is officially recorded GDP or real material measures, such as cars or colour television sets.

The best off countries, the Czech Republic, Slovenia and Hungary, are not so well off materially as the best off countries in the European Union. However, their living standards do not differ so much from the least well off EU member states, such as Portugal and Greece. The entry of the Czech Republic or Poland into the European Union does not require the achievement of German or Danish living standards. The majority of present member states of the Union have not done this. Every volume of Eurostat documents very big differences in material achievements among the fifteen member states of the Union.

The need for time. While there is no agreement within the European Union about whether the most desirable form of economy is a "free" or a "social" market, there is agreement that some kind of market economy is necessary. The move toward a Single European Market has increased the pressures for memberstates to have market institutions that are in harmony, even if not identical. In order for post-Communist societies to participate fully and positively in the European Union, they must have market economies too. For a country to join the European Union without laws of property, commercial banks, market prices, systems for clearing goods through customs quickly, etc., etc., would invite national disaster.

Central and East European countries are seeking to introduce market institutions. The first round of destabilizing events, such as hyperinflation and 
dramatic falls in measured official output, appears to have created in reaction a demand to reduce inflation and to have forced enterprises to become marketoriented. The process has now gone far enough so that it would be impossible for the institutions of the old command economy to be re-introduced. But creating the institutions and cadres of a modern market economy appears a much slower task than creating a pluralistic democracy. The mechanisms that individuals used to 'get by' in a command economy, such as growing food for home consumption, exchanging help in house repair with friends or working for the untaxed 'cash in hand' second economy, helps people avoid destitution, but does not lay the groundwork for enterprises that can operate in the single market (cf. Rose, 1993).

The legacy of Communism is a lack of many basic institutions of a modern market economy, such as a price system that reflected market factors, stable central bank and commercial banks, fixed laws of property and contract, a stock exchange, lawyers and accountancy firms, profit-oriented enterprise managers and exporters and administrators of firms in bankruptcy. Importing Westerners and Western techniques is inadequate, for outsiders are not trained to deal with the origins of problems in economies in transformation. In Britain, privatization could occur easily because there was already a private sector there, with sophisticated capital market institutions, small and large savers, and meaningful rather than misleading balance sheets and profit and loss statements. In the early days of transition there was a rush to "privatization without the private sector". Logically, to deal with these requires "transformation" managers, accountants and lawyers, people who understand both the old ways and new or emerging EU standards for the Single European Market. 
The problems of creating new institutions in a wreckage of a command economy are a reminder that institutions taken for granted in the West took generations to evolve. Without such institutions, a Single Europe Market cannot exist. It is in the interests of Central and East Europeans to construct such institutions for their own national wellbeing. It is even more in their interest to have such institutions well established before their manufacturing and service industries must face the full force of competition frum the current member states of the EU.

In social conditions, the countries of Central and Eastern Europe are notbackward. Literacy is complete, secondary education is common and tertiary education widespread. The contrast in human capital between Poland before the war, in the 1950s and today is extreme, just as it is between Italy or France over a similar length of time. None of the post-Communist countries reviewed here has labour force participation rates for women as low as those in the United Kingdom, Germany or Italy. In infant mortality, East Germany, Latvia and Lithuania in 1990 had already achieved a level as good as that of the threshold (that is, lowest-ranking) European Union country. Infant mortality is higher in other countries but as long as rates of progress can be maintained and any setbacks are not permanent, it is only a matter of time before infant mortality catches up with the current European Union threshold, or surpasses it. In gender equality in employment, Central and East European countries are actually ahead of European Union countries. There were 85 women employed for every 100 men in work in the median country there in 1990 , compared to 68 per 100 in the median European Union country at that time, a difference not eroded by economic transformation since (cf. Rose, 1994; UNICEF ICDC, 1994). 
What idea of Europe? The founders of the European Community had an idea of the Europe that they wished to create, and of a past that they wished to leave behind. Such ideals can never be completely realized, but they are political facts of first importance. As John Major demonstrates, the absence of any ideal is also important. In Central and East European lands invaded by Soviet troops at the end of the Second World War, joining the European Union was not available as an ideal, but governments there are now adopting Europe as a policy goal. But what idea do Central and East Europeans have of a Brussels-based Europe?

Public opinion surveys consistently show a low level of interest or knowledge about the European Union. The Central and Eastern European EuroBarometer (European Commission, 1993, Annex 29, 33 and 34) found that among for the seven countries examined here:

*Had heard of European Community or Common Market $\quad 79 \%$

*Interested in European Community $36 \%$

*Can name a city in which EC has major institutions $19 \%$

When Central and East Europeans are asked to evaluate European Union institutions, 53 per cent say they have neither a positive nor a negative impression of its aims and activities (Rose and Haerpfer, 1994: Q. 80). This is hardly surprising, given the low level of popular interest in European Union affairs. Among the minority with an impression, an average of 37 per cent reported a positive impression and 10 per cent a negative view. 
The low level of interest and knowledge about the European Union is a strong caution in interpreting current surveys showing that 52 per cent of Central and Eastern Europeans are 'somewhat in favour' of their country becoming a member of the European Union, and only 10 per cent express negative views (Rose and Haerpfer, 1994: Q. 81). The Maastricht referendums are a reminder that a referendum campaign is likely to produce a much more even division of voters than are surveys taken when the European Union is not a salient issue.

To focus on links between post-Communist countries and the European Union distorts the way in which peoples in Central and Eastern Europe see the world. The fact that people may be uninformed and uninterested in Europe qua Brussels does not mean that they are isolationist or parochial. When the Central and East European Barometer asks people to identify countries with which their future lies, a variety are named, including the United States. The orientation toward foreign countries is fragmented rather than focused on the European Union. Moreover, the answers vary with the geography and historic ties of the country (cf. European Commission, 1994: Figure 7, Annex Figures 10-13).

When Central and Eastern Europeans are asked whether they think their country should develop according to its own national traditions and values or follow those of West European countries, the majority give a patriotic response, endorsing their own national traditions (Table 6). Only in Slovenia do a majority turn to the West, almost certainly a rejection of their past as part of the Yugoslavia. The orientation to Western Europe is low in the Czech Republic as it is in Bulgaria. The assertion of national traditions and values is not unique to one part of Europe. In the wake of Maastricht, there are wrangle about symbols on a 
minted ecu, and a re-assertion of the idea of a Europe des patries (cf. Dahl, 1994 and Wallace, 1995).

(Table 6 about here)

The rejection of West European values is not a rejection of European values per se. People in Cracow can claim that they are just as much defenders of European civilization as are the people of Denmark or Spain, and Prague is more at the center of Europe than Dublin or Lisbon. In affirming national traditions people can be expressing a sense of a different Europe, in which the Danube not the Rhine is the main waterway. ${ }^{6}$ The European Union has a changing definition of Europe too. The accession of Finland, Sweden and Austria is a major step to the East. Further enlargement will not only have an impact upon peoples in postCommunist countries but also affect how the present member states of the Union define Europe.

\section{THE EU OBSTACLE: DEFINING THE ACQUIS COMMUNITAIRE}

If post-Communist states of Central and Eastern Europe are to be admitted to the European Union, the current members must be willing to accept their applications. Their current status can be described as "not unacceptable", for the associated countries have taken major strides since 1990 toward consolidating pluralistic political institutions. Countries selected for associate status are not without problems, but this is true of every democratic political system. Racism is a pan-European phenomenon, as witness the vote for LePen in France, and ethnic conflict in Northern Ireland has resulted in more violent deaths within the United Kingdom than in the transition from Communist rule to pluralistic democracy in nine of the ten Central and East European countries. 
Public opinion within the European Union is also not a barrier to enlargement; the preponderant view is positive or indifferent rather than negative. A survey by the Harris Research Centre (1994) shortly before the 1994 European Parliament election found an average of 50 per cent supported the idea of the Czech Republic, Slovakia, Hungary and Poland becoming members of the European Union, as against 30 per cent disapproving and 20 per cent with no opinion. Such data are best treated as showing a permissive public attitude as far as enlargement is concerned.

What will be the new acquis communitaire? To become a member, a country must accept the acquis communitaire. But countries of Central and Eastern Europe cannot agree to this until the current member states decide what it will be. The 1996 Inter-Governmental Council is intended to address this issue. Member states will simultaneously deal with issues left open in the Maastricht Treaty and anticipate issues that enlargement raises. Preparations indicate substantial divisions within and between national governments about the future direction of Europe.

The prospect of enlargement intensifies divisions that would exist if the Berlin Wall were still in place. These include disagreements about the existing Common Agricultural Policy, financial contributions by member states to the Union, the desirability or the feasibility of European monetary union, the rules for assigning votes and permitting vetoes by member states. The greater heterogeneity introduced into the Union by enlargement to the east will give added weight to arguments in favour of a 'variable geometry' Europe, potentially 
more divided than a 'two-speed' Europe. Future military security, inside or outside the European Union and with or without collaboration with the United States, is the only new issue raised by the collapse of the former Soviet Union.

Until the new acquis can be decided, there is nothing to be offered to countries expressing interest in joining the European Union. The InterGovernmental Conference is a starting point for facing these issues; agreement is unlikely to be reached by 31 December 1996. Whatever the extent of political progress in Central and Eastern Europe, at that time it is also unlikely that the institutions of a market economy will be fully functioning there.

To note that the future is open does not mean that the boundaries of Europe are static. Progress from a six-nation European Coal \& Steel Community to a European Union shows that even though change is erratic and often slow, both enlargement and deepening occur. The abrupt transition to freedom in Central and Eastern Europe is a reminder of how quickly great changes may take place there. And even if no enlargement occurs in the foreseeable future, the states and peoples of Central and Eastern Europe will not go away and cannot be ignored. The different parts of Europe are now interdependent, with or without sharing membership in the European Union, and this is clearest in the position of the richest and most powerful country in Central and Eastern Europe and of the European Union, the Federal Republic of Germany. 
References

Barber, Tony, 1994. "Hungary Set to Elect Former Communists", The Independent, 7 May.

Bridge, Adrian, 1994. "New Phase for EU as Hungary Asks To Join", The Independent (London), 2 April.

Churchill, Winston, 1947. "Debate", House of Commons Hansard (London: HMSO, 11 November) col. 206.

Dahl, Robert A., 1994. "A Democratic Dilemma: System Effectiveness versus Citizen Participation", Political Science Quarterly 109, 1, pp. 23-34.

European Commission, 1993. Central and Eastern EuroBarometer. Brussels: Commission of the European Communities No.3.

European Commission, 1994. Central and Eastern EuroBarometer. Brussels: Commission of the European Communities No.4.

Freedom House, 1994. "1994 Freedom Around the World", Ereedom Review, 25,1, 5-41.

Gibson, James L., 1993. "Personal Political Freedom in the Soviet Union", Journal of Politics, 55,4, 936-974,

Gunther, Richard, 1995. "The Nature and Consequences of Democracy in the New Southern Europe". Oxford: ESRC East/West Initiative Conference on Mass Response to the Transformation of Post-Communist Societies, 16-19 March.

Harris Research Centre, 1994. Euro Election Poll: Summary Report. Richmond Surrey: Harris Research Centre. 
Holzmann, Robert, Gacs, Janos, and Winckler, Georg, eds., 1995. Qutput Decline in Eastern Europe: Unavoidable, External Influence or Homemade? Dordrecht: Kluwer.

Kitschelt, Herbert, 1995. Party Systems in East Central Europe: Consolidation or Fluidity? Glasgow: University of Strathclyde Studies in Public Policy No. 241.

Kolankiewicz, George, 1994. "Consensus and Competition in the Eastern Enlargement of the European Union", International Affairs, vol. 70, pp. 477-495.

Kornai, Janos, 1992. The Socialist System: the Political Economy of Communism. Princeton: Princeton University Press.

Miller, W.L., White, S.L., and Heywood, P., 1995. "The Locus of Democratic Values".

Oxford: ESRC East/West Initiative Conference on Mass Response to the Transformation of Post-Communist Societies, 16-19 March.

Palma, Giuseppe di, 1990. To Craft Democracies. Berkeley: University of California Press.

Rose, Richard, 1993. "Contradictions between Micro and Macro-Economic Goals in Post-Communist Societies", European-Asian Studies (formerly, Soviet Studies), 45,3, 419-444.

Rose, Richard, 1994. Comparing Welfare Across Time and Space. Vienna: European

Centre for Social Welfare Policy and Research, Eurosocial Report 49. 
Rose, Richard, 1995. "Freedom as a Fundamental Value", International Social Science Journal, in press.

Rose, Richard, 1996. What Is Europe? A Dynamic Perspective. London and New York: Harper Collins.

Rose, Richard and Carnaghan, Ellen, 1995. "Generational Effects on Attitudes to Communist Regimes: a Comparative Analysis". Post-Soviet Affairs, 11,1, 28-56.

Rose, Richard and Haerpfer, Christian, 1994. New Democracies Barometer III. Glasgow: U. of Strathclyde Studies in Public Policy No. 230.

Rose, Richard and Maley, William, 1994. "Conflict or Compromise in the Baltic States?", RFE/RL Research Report 3, 28 (1994), pp. 26-35.

Rose, Richard and Mishler, William T.E., 1994. "Mass Reaction to Regime Change in Eastern Europe: Polarization or Leadr.s and Laggards?', British Journal of Political Science, 24,2, 159-82.

Rose, Richard and Mishler, William T.E., 1994a. Representation and Effective Leadership in Post-Communist Political Systems. Glasgow: U. of Strathclyde Studies in Public Policy No. 232.

Rose, Richard and Page, Fidward C.. 1996. "German Responses to Regime Change: Culture, Class, Economy or Context?", West European Politics, in press.

Rose, Richard, Zapf, Wolfgang, Seifert, Wolfgang, and Page, Edward C., 1993. Germans in Comparative Perspective. Glasgow: University of Strathclyde Studies in Public Policy No. 218. 
Schumpeter, Joseph A., 1952. Capitalism, Socialism and Democracy. London: George Allen \& Unwin.

Summers, Lawrence, 1992. 'The Next Decade in Central and Eastern Europe'. In Clague, Christopher and Rausser, Gordon, eds., The Emergence of Market Economies in Eastern Europe. Cambridge, MA: Blackwell, 25-34.

UNICEF ICDC (International Child Development Centre), 1994. Public Policy and Social Conditions: Central and Eastern Europe in Transition. Florence, italy: UNICEF ICDC Regional Monitoring Report No. 1.

Wallace, William, 1995. "Rescue or Retreat? The Nation State in Western Europe, 1945-93", Political Studies 42, special issue, pp. 52-76.

Weil, Frederick D, 1989, 'The Sources and Structure of Legitimation in Western Democracies', American Sociological Review, 54, 4, 682-706.

White, Stephen, ed., 1990. "Elections in Eastern Europe", a special issue of Electoral Studies, 9, 4, 275-366.

White, Stephen and McAllister, Ian, forthcoming. "The CPSU and its Members in Postcommunist Russia", British Journal of Political Science.

World Bank, 1993. Historically Planned Economies: A Guide to the Data. Washington, DC: World Bank. 
Table 1 EVALUATING POLITICAL REGIMES--PAST,PRESENT,FUTURE

$\begin{array}{lrr}\text { Communist } & \begin{array}{c}\text { Current } \\ \text { regime }\end{array} & \begin{array}{c}\text { In five } \\ \text { regime }\end{array} \\ & \text { (\% rating positive })\end{array}$

\begin{tabular}{llll} 
Bulgaria & 51 & 59 & 70 \\
Czech Republic & 23 & 78 & 88 \\
Slovak Republic & 50 & 52 & 79 \\
Hungary & 58 & 51 & 76 \\
Poland & 38 & 69 & 84 \\
Romania & 33 & 60 & 77 \\
Slovenia & 32 & 55 & 72 \\
\multicolumn{1}{c}{ Mean } & --- & --- & --- \\
& 41 & 61 & 78
\end{tabular}

East Germany

32

60

64

Source: Paul Lazarsfeld Society, Vienna, New Democracies Barometer III. A multi-national survey conducted between late November, 1993 and early March, 1994, sponsored by the Austrian Federal Ministry for Science and Research and the Austrian National Bank. Total number of respondents: 7,020. For full details, see R. Rose and Christian Haerpfer, New Democracies Barometer III (Glasgow: Strathclyde Studies in Public Policy No. 232). East German results from a spring, 1993 representative sample survey of 1,117 respondents (see Rose, Zapf et al., 1993). 
Table 2 EVALUATING ECONOMIC SYSTEMS--PAST, PRESENT,FUTURE

\begin{tabular}{lcc} 
Communist & \multicolumn{2}{c}{ Transition In five } \\
system & system years \\
& $(\%$ rating positive $)$
\end{tabular}

Bulgaria

$\begin{array}{lll}66 & 15 & 56 \\ 42 & 66 & 86 \\ 74 & 31 & 73 \\ 75 & 27 & 63 \\ 52 & 50 & 71 \\ 60 & 35 & 66 \\ 48 & 48 & 73 \\ --- & -- & -- \\ 60 & 39 & 70\end{array}$

Czech Republic

Slovak Republic

Hungary

Poland

Romania

Slovenia

Mean

36

75

82

East Germany

56

86

73

66

3

70

2

Source: Paul Lazarsfeld Society, New Democracy Barometer III and 1993 East German survey; see Table 1. 
39

Table 3 INCREASED FREEDOMS IN EAST EUROPEAN NEW DEMOCRACIES

\begin{tabular}{|c|c|c|c|c|c|}
\hline & Speech & Join & Travel & No fear & Interest \\
\hline \multicolumn{6}{|l|}{ Religion } \\
\hline & & org. & & arrest & politics \\
\hline
\end{tabular}

$\begin{array}{lllllll}\text { Bulgaria } & 90 & 95 & 95 & 88 & 97 & 98 \\ \text { Czech Republic } & 84 & 90 & 96 & 73 & 84 & 94 \\ \text { Slovakia } & 82 & 88 & 88 & 62 & 80 & 96 \\ \text { Hungary } & 73 & 81 & 76 & 59 & \text { na } & 83 \\ \text { Poland } & 83 & 78 & 75 & 71 & 69 & 70 \\ \text { Romania } & 94 & 94 & 90 & 81 & 92 & 95 \\ \text { Slovenia } & 74 & 82 & 62 & 54 & 59 & 77 \\ & -- & -- & -- & -- & -- & -- \\ \text { Mean } & 80 & 84 & 72 & 62 & 74 & 86\end{array}$

Source: Paul Lazarsfeld Society, New Democracies Barometer III. 
Table 4 WHAT ARE THE ALTERNATIVES?

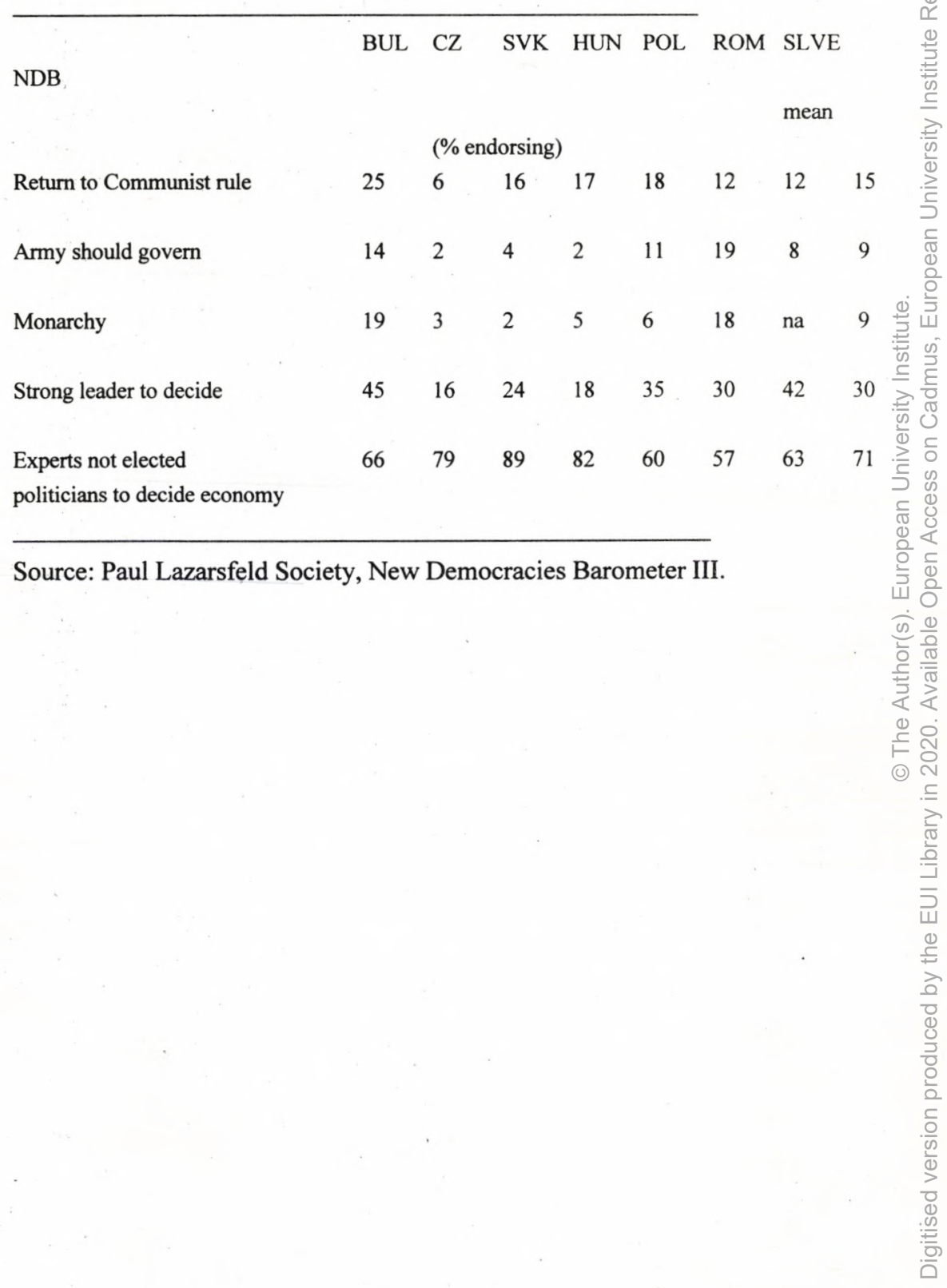


Table 5 VALUES OF EX-COMMUNISTS AND NON-COMMUNISTS COMPARED

Ex-Com'st Com'st Non-Com'st Diff'ce
in family

(\% approving)

Communist political regime

Current political regime

Future political regime

Past economic system

Current economic system

Future economic system

More freedom now to say what think

Return to Communist rule

Strong leader to decide

Experts decide economy

Approve suspension Parliament
48

60

77

68

34

69

82

18

28

66

21
38

61

81

59

39

73

85

14

27

69

22
36

63

78

1

54

14

44

72

85

14

34

70

25

(Questions cross-tabulated by replies to a question about whether the respondent or any member of his or her family had belonged to the Communist Party or an associated organization. Answers pooled for six Central and Eastern countries covered in Tables 1-4; party membership was not asked in Slovenia.)

Source: Paul Lazarsfeld Society, New Democracies Barometer III. 
Table 6 ORIENTATION TO WESTERN EUROPE OR NATIONAL TRADITIONS?

\section{Bulg $\mathrm{Cz}$ Hung Slvk Rom. Slovenia Mean \\ ( $\%$ endorsing each alternative)}

National traditions, values

Western Europe

No answer
63 63.63 59 57 52 33 $\begin{array}{llllll}35 & 36 & 35 & 41 & 47 & 65\end{array}$

$\begin{array}{llllll}2 & 1 & 5 & 2 & 2 & 2\end{array}$

Q. Do you think our country should develop like West European countries or should our country develop in keeping with our national traditions and values?

Source: Paul Lazarsfeld Society, New Democracies Barometer III. Question not asked in Poland. 


\section{End Notes}

1. Any definition of Central and Eastern Europe must exclude as well as include countries (see Rose, 1996: chapter 14). This is recognized by the Council of Europe, which uses democracy as a criterion separating the region from the historic republics of the former Soviet Union. Successor states of Yugoslavia are, pro tempore, excluded, except for Slovenia, which is outside the war zone and a democracy. The inclusiveness of the CSCE (Conference on Security and Cooperation in Europe) arises from a desire to include nuclear powers and successor states of the USSR.

2. The New Democracies Barometer also included Croatia, Belarus and the Ukraine. As these countries are not recognized as potential candidates for membership in the EU in the near term, they are excluded here. The Baltic states of Estonia, Latvia and Lithuania are also potential candidates for membership in the European Union. The very large Russian minorities introduced to Estonia and Latvia following the Second World War create substantial political complications there. For survey data on these countries, see Rose and Maley (1994).

3. Support for a democratic regime does not require every citizen to hold "democratic" values, however defined. For example, Gibson (1993: 949) has shown that on some measures democratic values are no greater among American blacks than among Russians whom he surveyed, and Miller (1995) has drawn a similar conclusion from responses of Britons, Russians, Ukrainians, Hungarians and Czechs. 
4. Because of the deviant circumstances of East Germany, it is excluded from most tables. For a more detailed analysis and comparison with West Germans, see Rose and Page (1996).

5. This hypothesis does not assume that Communist Party members are all of one mind about democracy, an assumption that would deny political differences of opinion. It simply states that divisions among Communists and among nonCommunists should be similar.

6. Even on this, Central and East Europeans divide, for the river that flows through Prague proceeds via Germany to the North Sea, and states on the Baltic have a different outlook than those with a Balkan aspect. 
Bibliographical notes

Professor Richard Rose FBA leads a programme of annual nationwide surveys monitoring trends in mass response to postCommunist societies between state and market, covering 15 countries of Central and Eastern Europe and the former Soviet Union. It commenced in 1991 and more than 60 surveys are now in its data base. He is director of the Centre for the Study of Public Policy, University of Strathclyde, Glasgow, Scotland and international scientific advisor of the Paul Lazarsfeld Society.

Dr. Christian Haerpfer is scientific director of the Paul Lazarsfeld Society, Vienna, and co-founder of the multi-national New Democracies Barometer. He is the author of numerous books and articles in English and German on Austrian politics and comparative political behaviour. 


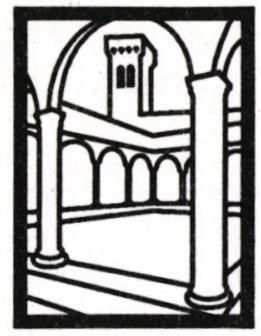

EUI WORKING PAPERS

EUI Working Papers are published and distributed by the European University Institute, Florence

Copies can be obtained free of charge

- depending on the availability of stocks - from:

The Publications Officer

European University Institute

Badia Fiesolana

I-50016 San Domenico di Fiesole (FI)

Italy 


\title{
Publications of the European University Institute
}

To

\author{
The Publications Officer \\ European University Institute \\ Badia Fiesolana \\ I-50016 San Domenico di Fiesole (FI) - Italy \\ Telefax No: $+39 / 55 / 573728$ \\ E-mail: publish@datacomm.iue.it
}

From

Name

Address.

$\square$ Please send me a complete list of EUI Working Papers

$\square$ Please send me a complete list of EUI book publications

$\square$ Please send me the EUI brochure Academic Year 1996/97

Please send me the following EUI Working Paper(s):

No, Author

Title:

No, Author

Title:

No, Author

Title:

No, Author

Title:

Date

Signature 


\section{Working Papers of the Robert Schuman Centre}

RSC No. 94/1

Fritz W. SCHARPF

Community and Autonomy Multilevel

Policy-Making in the European Union

\section{RSC No. 94/2}

Paul McALEAVEY

The Political Logic of the European

Community Structural Funds Budget:

Lobbying Efforts by Declining Industrial

Regions

RSC No. $94 / 3$

Toshihiro HORIUCHI

Japanese Public Policy for Cooperative

Supply of Credit Guarantee to Small Firms -

Its Evolution Since the Post War and Banks'

Commitment

RSC No. 94/4

Thomas CHRISTIANSEN

European Integration Between Political

Science and International Relations Theory:

The End of Sovereignty *

RSC No. 94/5

Stefaan DE RYNCK

The Europeanization of Regional

Development Policies in the Flemish Region

RSC No. 94/6

Enrique ALBEROLA ILA

Convergence Bands: A Proposal to Reform the EMS in the Transition to a Common Currency

RSC No. 94/7

Rosalyn HIGGINS

The EC and the New United Nations

RSC No. 94/8

Sidney TARROW

Social Movements in Europe: Movement

Society or Europeanization of Conflict?

RSC No. $94 / 9$

Vojin DIMITRIJEVIC

The 1974 Constitution as a Factor in the

Collapse of Yugoslavia or as a Sign of

Decaying Totalitarianism
RSC No. $94 / 10$

Susan STRANGE

European Business in Japan: A Policy

Crossroads?

RSC No. $94 / 11$

Milica UVALIC

Privatization in Disintegrating East European

States: The Case of Former Yugoslavia

RSC No. $94 / 12$

Alberto CHILOSI

Property and Management Privatization in

Eastern European Transition: Economic

Consequences of Alternative Privatization

Processes

RSC No. 94/13

Richard SINNOTT

Integration Theory, Subsidiarity and the

Internationalisation of Issues: The

Implications for Legitimacy *

RSC No. 94/14

Simon JOHNSON/Heidi KROLL

Complementarities, Managers and Mass

Privatization Programs after Communism

RSC No. 94/15

Renzo DAVIDDI

Privatization in the Transition to a Market

Economy

RSC No. $94 / 16$

Alberto BACCINI

Industrial Organization and the Financing of

Small Firms: The Case of MagneTek

RSC No. 94/17

Jonathan GOLUB

The Pivotal Role of British Sovereignty in EC Environmental Policy

RSC No. $94 / 18$

Peter Viggo JAKOBSEN

Multilateralism Matters but How?

The Impact of Multilateralism on Great

Power Policy Towards the Break-up of

Yugoslavia 
RSC No. $94 / 19$

Andrea BOSCO

A 'Federator' for Europe: Altiero Spinelli and the Constituent Role of the European Parliament

RSC No. $94 / 20$

Johnny LAURSEN

Blueprints of Nordic Integration. Dynamics and Institutions in Nordic Cooperation, 1945-72

\section{*** $*$}

RSC No. 95/1

Giandomenico MAJONE

Mutual Trust, Credible Commitments and the Evolution of Rules for a Single

European Market

RSC No. 95/2

Ute COLLIER

Electricity Privatisation and Environmental

Policy in the UK: Some Lessons for the

Rest of Europe

RSC No. 95/3

Giulians GEMELLI

American Influence on European

Management Education: The Role of the Ford Foundation

RSC No. 95/4

Renaud DEHOUSSE

Institutional Reform in the European

Community: Are there Alternatives to the Majoritarian Avenue?

RSC No. 95/5

Vivien A. SCHMIDT

The New World Order, Incorporated:

The Rise of Business and the Decline of the Nation-State

RSC No. 95/6

Liesbet HOOGHE

Subnational Mobilisation in the European

Union

RSC No. 95/7

Gary MARKS/Liesbet HOOGHE/Kermit BLANK

European Integration and the State
RSC No. 95/8

Sonia LUCARELLI

The International Community and the

Yugoslav Crisis: A Chronology of Events

RSC No. 95/9

A Constitution for the European Union?

Proceedings of a Conference, 12-13 May 1994,

Organized by the Robert Schuman Centre with the

Patronage of the European Parliament

RSC No. 95/10

Martin RHODES

'Subversive Liberalism': Market Integration, Globalisation and the European Welfare

State

RSC No. $95 / 11$

Joseph H.H. WEILER/ Ulrich HALTERN/

Franz MAYER

European Democracy and its Critique -

Five Uneasy Pieces

RSC No. 95/12

Richard ROSE/Christian HAERPFER

Democracy and Enlarging the European

Union Eastward 


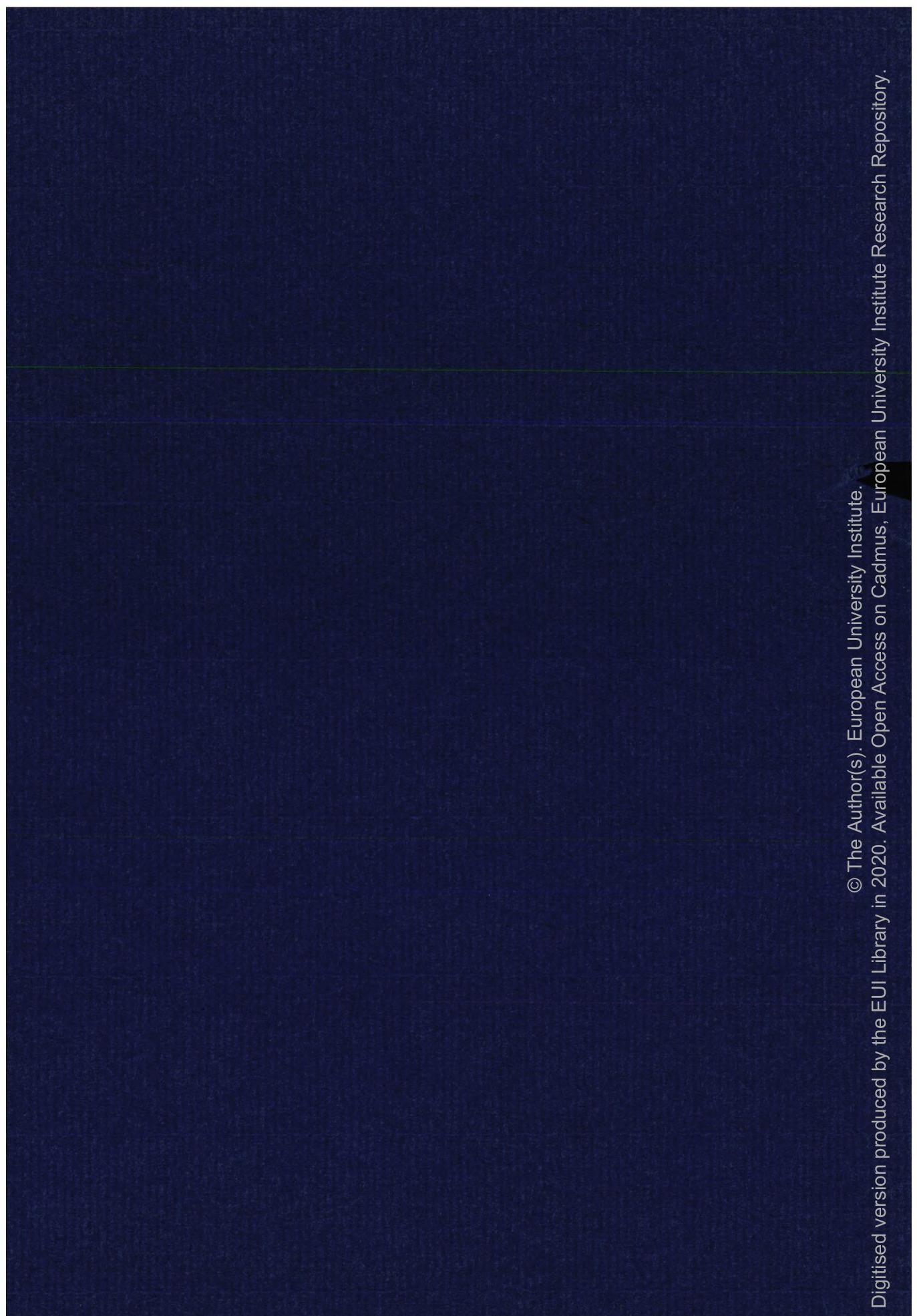




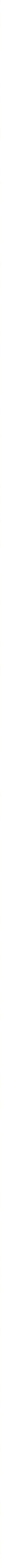

